\begin{tabular}{ll}
\hline Homepage: http://jusami.batan.go.id & Jurnal Sains Materi Indonesia \\
\hline & $\begin{array}{l}\text { Akreditasi LIPI } \\
\text { No.: 602/AU3/P2MI-LIPI/03/2015 } \\
\text { ISSN : 1411-1098 }\end{array}$ \\
\hline
\end{tabular}

\title{
PENGARUH RASIO MASSA KITIN/NaOH DAN WAKTU REAKSI TERHADAP KARAKTERISTIK KITOSAN YANG DISINTESIS DARI LIMBAH INDUSTRI UDANG KERING
}

\author{
Ahmad Fadli ${ }^{1}$, Drastinawati ${ }^{1}$, Ongky Alexander ${ }^{1}$ dan Feblil Huda ${ }^{2}$ \\ ${ }^{1}$ Jurusan Teknik Kimia, Fakultas Teknik - Universitas Riau \\ Jl. HR. Subrantas Km 12,5 Panam, Pekanbaru 28293 Riau \\ ${ }^{2}$ Jurusan Teknik Mesin, Fakultas Teknik - Universitas Riau \\ Jl. HR. Subrantas Km 12,5 Panam, Pekanbaru 28293 Riau \\ E-mail:fadliunri@yahoo.com
}

Diterima: 18 Oktober 2016

Diperbaiki: 21 Desember 2016

Disetujui: 5 Januari 2017

\begin{abstract}
ABSTRAK
PENGARUH RASIO MASSA KITIN/NaOH DAN WAKTU REAKSI TERHADAP KARAKTERISTIK KITOSAN YANG DISINTESIS DARI LIMBAH INDUSTRI UDANG KERING. Kitosan merupakan polimer yang dapat dibuat dari kitin menggunakan proses deasetilasi. Tujuan penelitian ini untuk mempelajari pengaruh rasio massa kitin dengan volume $\mathrm{NaOH}$ dan waktu reaksi terhadap karakteristik kitosan yang disintesis dari limbah industri udang kering. Kitin diisolasi dari cangkang udang dengan metode deproteinasi dan demineralisasi. Deasetilasi kitin dilakukan pada suhu $120^{\circ} \mathrm{C}$, kecepatan pengadukan $150 \mathrm{rpm}$, rasio massa kitin dengan volume $\mathrm{NaOH}$ 1:15, 1:20, 1:25 (w/v), dan waktu reaksi 0,5-3 jam. Hasil penelitian menunjukkan bahwa peningkatan nilai rasio massa kitin dengan volume $\mathrm{NaOH}$ terhadap waktu reaksi mengakibatkan peningkatan derajat deasetilasi dan penyusutan kadar abu dan rendemen kitosan, sedangkan kadar air tidak memiliki efek yang signifikan. Derajat deasetilasi kitosan adalah 85,7\% pada rasio massa kitin dengan volume $\mathrm{NaOH}$ 1:15 selama 3 jam dan meningkat menjadi 86,1\% setelah rasio massa kitin dengan volume $\mathrm{NaOH}$ ditingkatkan menjadi 1:25. Kadar rendemen berkisar antara 86,6\% hingga 63,5 \%, kadar air kitosan berkisar antara $1,2 \%$ hingga 1,0 \%, dan kadar abu kitosan berkisar antara 1,9\% hingga $1,1 \%$.
\end{abstract}

Kata kunci: Deasetilasi, Demineralisasi, Deproteinasi, Kitin, Kitosan

\begin{abstract}
EFFECT OF CHITIN MASS/NaOH RATIO AND REACTION TIME ON CHARACTERISTICS OF CHITOSAN SYNTHESIZED FROM WASTE OF DRIED SHRIMP INDUSTRY. Chitosan is a polymer can be prepared from chitin using deacetylation process. The purpose of this research is to study the effect of ratio of chitin mass to $\mathrm{NaOH}$ volume and reaction time on characteristic of chitosan synthesized from waste of dried shrimp industry. Firstly, chitin was isolated from shrimp shell waste with deproteination and demineralization methods. Subsequenly, chitin was transformed into chitosan by deacetylation process at $120^{\circ} \mathrm{C}$, stirring rate of $150 \mathrm{rpm}$, ratio chitin mass to $\mathrm{NaOH}$ volume of $1: 15,1: 20,1: 25(\mathrm{w} / \mathrm{v})$ and reaction time of 0.5 to 3 hours. This research result indicate that when ratio of chitin mass to $\mathrm{NaOH}$ volume increase, the degree of deacetylation of chitosan increased also but the amounts of ash and yield of chitosan decrease, whereas water content not appear significant effect. Degree of deacetylation of chitosan is $85,7 \%$ with ratio chitin mass to $\mathrm{NaOH}$ volume $1: 15$ during 3 hours, then it increase to $86,1 \%$ after ratio chitin mass to $\mathrm{NaOH}$ volume increased ratio to $1: 25$. Yield of chitosan is in the range $86.6 \%$ to $63.5 \%$, water content is $1.2 \%$ to $1.0 \%$, and amount of ash is $1.9 \%$ to $1.1 \%$.
\end{abstract}

Keywords: Chitin, Chitosan, Deacetylation, Demineralization, Deproteination 


\section{PENDAHULUAN}

Kitosan adalah poli-(2-amino-2-deoksi- $\beta$-(1-4)-Dglukopiranosa) dihasilkan dari kitin melalui proses deasetilasi dengan menghilangkan gugus asetil $\left(\mathrm{CH}_{3}-\mathrm{CO}\right)$ dengan atom hidrogen $(\mathrm{H})$ atau mengubah gugus asetamida (-NHCOCH$)_{3}$ pada kitin menjadi gugus amina $\left(\mathrm{NH}_{2}\right)$ [1,2]. Kitin terdiri dari rantai lurus gugus acetylglucosamine, merupakan polisakarida dengan ikatan $\beta$-glikosidik $(1,4)[3,4]$.

Kitosan bersifat biokompatibel, biodegradabel, biofungsional, dan tidak toksik sehingga kitosan banyak digunakan di bidang kesehatan sebagai growth factor. Kitosan dapat diperoleh dari cangkang udang dan kepiting. Cangkang udang mengandung $24 \%$ kitosan [5]. Sintesis kitosan telah dilakukan sebelumnya. Long (2013) mereaksikan cangkang udang dengan $\mathrm{NaOH} 12,5 \mathrm{~N}$ $\left(100{ }^{\circ} \mathrm{C}, 10 \mathrm{jam}\right)$ dan diperoleh derajat deasetilasi $80,5 \%[6]$.

Kitosan dengan derajat deasetilasi $81,2 \%$ didapatkan oleh Hossain dengan membuat reaksi limbah udang dan $\mathrm{NaOH} 60 \%\left(60{ }^{\circ} \mathrm{C}, 24\right.$ jam $)$ [4]. Derajat deasetilasi yang diperoleh dari cangkang udang Penaeuscarinatus dan Penaeusmonodon dengan $\mathrm{NaOH} 50 \%\left(100{ }^{\circ} \mathrm{C}, 2\right.$ jam) adalah $89,4 \%$ [7]. Kitosan dengan derajat deasetilasi $89,8 \%$ telah diekstraksi dari udang laut Fenneropenaeus indicu dengan merendamnya di dalam $\mathrm{NaOH} 4 \%$ diikuti dengan deasetilasi dengan $\mathrm{NaOH} 50 \%\left(100{ }^{\circ} \mathrm{C}, 2\right.$ jam, 50 rpm) [8].

Ebi atau udang kering adalah produk olahan hasil perikanan dengan bahan baku udang segar melalui proses pengupasan kulit dan pengolahan dengan pengeringan. Jenis udang yang digunakan adalah udang api-api (Metapenaeus monoceros) dan udang krosok (Metapenaeus lysianassa).

Sementara itu, cangkang udang dari industri ebi merupakan limbah padat dalam jumlah berlimpah yang selama ini umumnya digunakan untuk pakan dan pupuk dengan harga yang murah [9].

Tujuan penelitian ini memanfaatkan cangkang udang (Metapenaeus monoceros) dan udang krosok (Metapenaeus lysianassa) dari limbah industri ebi sebagai bahan dasar pembuatan kitosan. Pengaruh rasio massa kitin/volume $\mathrm{NaOH}$ dan waktu reaksi dievalusi terhadap karakteristik kitosan.

\section{METODE PERCOBAAN}

\section{Bahan}

Bahan yang digunakan dalam penelitian ini, yaitu limbah cangkang udang yang diperoleh dari hasil samping pengolahan industri udang kering (ebi) dari desa Kuala Enok Kecamatan Indragiri Hilir-Riau, $\mathrm{NaOH}$ (Merck, Jerman), $\mathrm{HCl}$ (Merck, Jerman) dan aquadest.

\section{Cara Kerja}

\section{Sintesis Kitin}

Limbah ebi dicuci dengan akuades dan dikeringkan di dalam oven $\left(105^{\circ} \mathrm{C}\right)$, dihaluskan dan diayak menggunakan ayakan 50 mesh. Sintesis kitosan dilakukan menggunakan metode yang telah dilakukan sebelumnya [10]. Serbuk cangkang udang dicampur dengan larutan $\mathrm{NaOH} 3,5 \%$. Rasio cangkang udang dan $\mathrm{NaOH}$ adalah 1:10 (berat/volume) pada suhu $65^{\circ} \mathrm{C}$ selama 2 jam dan diaduk dengan kecepatan $150 \mathrm{rpm}$. Serbuk cangkang udang disaring dan dicuci dengan aquadest hingga $\mathrm{pH}$ netral, dikeringkan di dalam oven $\left(100^{\circ} \mathrm{C}, 4\right.$ jam $)$.

Serbuk ini kemudian dihilangkan kadar mineralnya (demineralisasi) dengan mencampurkannya dengan $\mathrm{HCl}$ $1 \mathrm{~N}$ pada suhu $30{ }^{\circ} \mathrm{C}$ selama 1 jam dan pengadukan $150 \mathrm{rpm}$ dengan rasio berat cangkang udang dengan volume larutan 01:15 (b/v) di dalam gelas kimia $500 \mathrm{~mL}$. Penyaringan dilakukan untuk diambil residunya dan dicuci dengan akuades hingga $\mathrm{pH}$ netral. Endapan kitin yang dihasilkan kemudian dikeringkan di dalam oven pada suhu $100{ }^{\circ} \mathrm{C}$ selama 4 jam.

\section{Sintesis Kitosan}

Sebanyak10 gram kitin dilarutkan dengan $200 \mathrm{~mL}$ $\mathrm{NaOH} 50 \%$. Rasio massa kitin dengan larutan $\mathrm{NaOH}$ adalah 01:15, 01:20 dan 01:25 (b/v) pada suhu $120^{\circ} \mathrm{C}$. Variasi waktu reaksi adalah 0,$5 ; 1 ; 1,5 ; 2 ; 2,5$ dan 3 jam dengan pengadukan konstan $150 \mathrm{rpm}$. Campuran hasil proses deasetilasi disaring, filtratnya dicuci dengan akuades hingga $\mathrm{pH}$ netral, dan dikeringkan dalam oven $\left(100^{\circ} \mathrm{C}, 4 \mathrm{jam}\right)$.

\section{Karakterisasi Kitosan}

Gugus fungsi yang ada di dalam kitosan dianalisis menggunakan FT-IR. Rendemen dihitung berdasarkan Persamaan (1) sebagai berikut:

Rendemen $\%=\frac{\text { massa kitosan kering (gram) }}{\text { massa kitin kering }(\text { gram })} \times 100 \%$ ... (1)

Cawan porselen dikeringkan di dalam oven (105 ${ }^{\circ} \mathrm{C}, 15$ menit), disimpan di dalam desikator ( \pm 15 menit), lalu ditimbang. Sebanyak 5 gram sampel di masukkan ke dalam cawan, dipanaskan di dalam oven ( $105^{\circ} \mathrm{C}, 30$ menit, disimpan di dalam desikator ( \pm 15 menit), lalu ditimbang hingga beratnya konstan. Kadar air dihitung dengan Persamaan (2) berikut :

$$
\text { Kadar air } \%=\frac{(B 1-B 2)}{B 1} \times 100 \%
$$

B1 dan B2 adalah berat sampel sebelum dan setelah dikeringkan. 
Sebanyak 0,5 gram kitosan ke dalam cawan porselin yang telah diketahui bobotnya. Selanjutnya, kitosan tersebut dibakar dalam furnace bersuhu $600{ }^{\circ} \mathrm{C}$ sampai diperoleh abu berwarna putih. Setelah itu, cawan tersebut didinginkan dalam desikator dan ditimbang. Kadar abu dihitung dengan Persamaan (3) berikut:

Kadar abu $\%=\frac{\text { berat abu (gram) }}{\text { berat kitosan awal (gram) }} \times 100 \% \ldots$.

Histogram yang diperoleh dari analisis FT-IR digunakan untuk menghitung derajat deasetilasi dari kitosan. Puncak tertinggi $\left(\mathrm{P}_{0}\right)$ dan puncak terendah $(\mathrm{P})$ diukur dengan garis dasar yang dipilih. Nisbah absorbansi dihitung dengan rumus seperti Persamaan (4) [7] :

$$
A=\log \frac{\mathrm{p}_{0}}{\mathrm{P}}
$$

Dimana:

$$
\begin{aligned}
\mathrm{A}= & \text { Absorbansi } \\
\mathrm{PO}= & \% \text { transmitans pada garis dasar, dengan } \\
& \text { panjang gelombang } 1.655 \mathrm{~cm}^{-1} \text { atau } 3.450 \mathrm{~cm}^{-1} \\
\mathrm{P}= & \% \text { transmitans pada puncuk minimun dengan } \\
& \text { panjang gelombang } 1.655 \mathrm{~cm}^{-1} \text { atau } 3.450 \mathrm{~cm}^{-1}
\end{aligned}
$$

Perbandingan absorbansi pada $1.655 \mathrm{~cm}^{-1}$ dengan absorbansi $3.450 \mathrm{~cm}^{-1}$ digandakan satu per standar $\mathrm{N}$-deasetilasi kitosan $(1,33)$. Dengan mengukur absorbansi pada puncak yang berhubungan, nilai persentase $\mathrm{N}$-deasetilasi dapat dihitung dengan rumus Persamaan (5) [11]:

$\%$ Derajat deasetilasi $=\left[1-\left[\frac{A_{1.655}}{A_{8.450}} \times \frac{1}{1,33}\right]\right]$

Dimana:

$$
\begin{aligned}
\text { A1.655 }= & \text { Absorbansi pada bilangan gelombang } \\
& 1.655 \mathrm{~cm}^{-1} \\
\mathrm{~A} 3.450= & \text { Absorbansi pada bilangan gelombang } \\
& 3.450 \mathrm{~cm}^{-1} \\
1,33= & \text { Konstanta untuk derajat deasetilasi } \\
& \text { yang sempurna }
\end{aligned}
$$

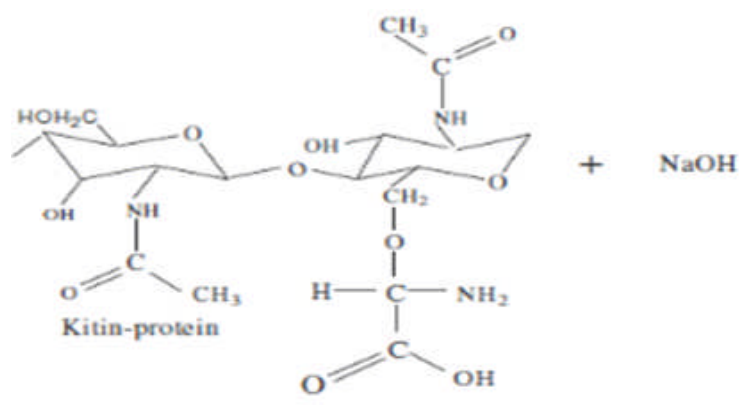

\section{HASIL DAN PEMBAHASAN}

\section{Isolasi Kitin}

Isolasi kitin dari limbah udang bertujuan memisahkan kitin dari protein dan kalsium karbonat. Pada tahap deproteinasi, protein yang terkandung dalam limbah ebi akan larut dalam basa sehingga protein yang terikat secara kovalen pada gugus fungsi kitin akan terpisah. Perolehan rendemen limbah ebi hasil deproteinasi pada penelitian ini sebesar $61 \%$. Hal ini mengindikasikan bahwa kandungan protein dalam cangkang udang sudah terlepas dan bereksi dengan $\mathrm{NaOH}$ membentuk asam amino dengan persamaan reaksi terlihat pada Gambar 1 [12]. Tahap deproteinasi menggunakan $\mathrm{NaOH} 3,5 \%$ dengan tujuan untuk memisahkan ikatan-ikatan protein dari kitin. $\mathrm{NaOH}$ bisa digunakan dalam industri pada rentang konsentrasi $0,125 \mathrm{M}$ hingga $5 \mathrm{M}$ dan variasi suhu hingga mencapai $160^{\circ} \mathrm{C}[13]$.

Selain mengandung kitin, limbah udang hasil proses deproteinasi juga mengandung mineral. Mineral utama pada cangkang udang adalah kalsium karbonat $\left(\mathrm{CaCO}_{3}\right)$ dan kalsium posfat $\left(\mathrm{Ca}_{3}\left(\mathrm{PO}_{4}\right)_{2}\right)$. Mineral tersebut dapat dihilangkan dari matriks dengan menggunakan larutan $\mathrm{HCl} 1 \mathrm{~N}$ [10]. Nilai rendemen kitin menurun dari $61 \%$ (hasil deproteinasi) menjadi sebesar $16 \%$ setelah proses demineralisasi. Berkurangnya massa padatan kitin ini disebabkan kandungan mineral yang hilang pada cangkang udang selama proses demineralisasi juga berkurang.

Kitin yang diperoleh diidentifikasi menggunakan FT-IR (Gambar 2). Spektrum kitin menunjukkan serapan vibrasi gugus $\mathrm{OH}$ yang melebar, yaitu pada $3500 \mathrm{~cm}^{-1}$, vibrasi ulur N-H pada $3255,02 \mathrm{~cm}^{-1}$. Serapan pada $2890,45 \mathrm{~cm}^{-1}$ merupakan uluran dari C-H. Vibrasi ulur untuk $\mathrm{C}=\mathrm{O}$ pada $1680,01 \mathrm{~cm}^{-1}$, vibrasi untuk bengkokan $\mathrm{N}-\mathrm{H}$ muncul pada bilangan gelombang $1554,167 \mathrm{~cm}^{-1}$. Serapan $\mathrm{CH}_{3}$ pada $1416,667 \mathrm{~cm}^{-1}$. Serapan $1072,42 \mathrm{~cm}^{-1}$ menunjukkan adanya vibrasi C-O-C dalam cincin kitin dan pada $666,67 \mathrm{~cm}^{-1}$ untuk serapan N-H kibasan. Adanya

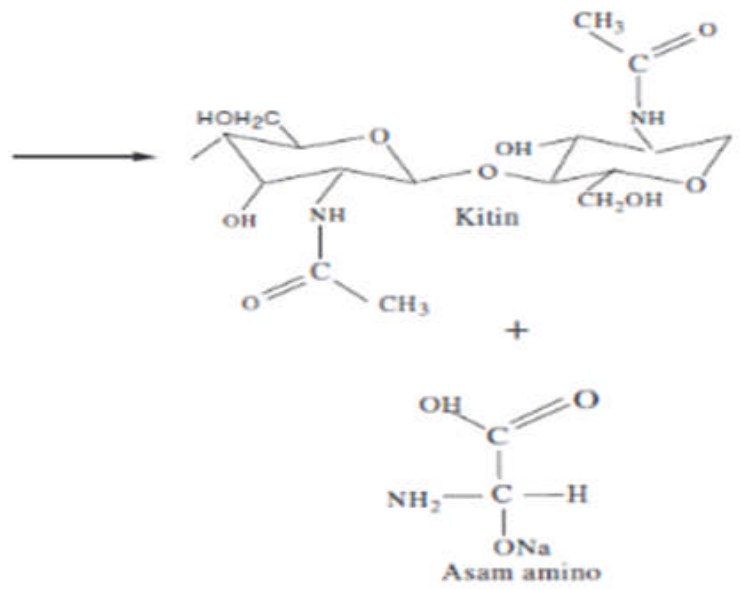

Gambar 1. Reaksi deproteinasi secara kimiawi pada proses isolasi kitin [14]. 


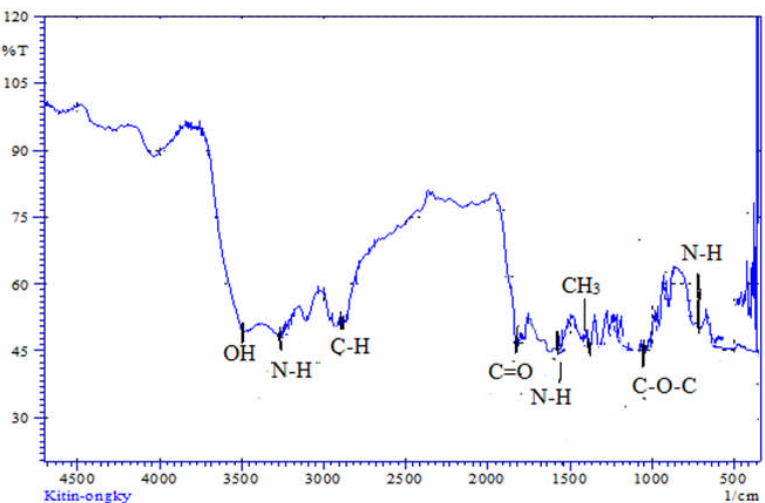

Gambar 2. Analisis gugus fungsi kitin dengan FT-IR

spektrum vibrasi $\mathrm{O}-\mathrm{H}, \mathrm{C}-\mathrm{H}, \mathrm{CH}_{3}, \mathrm{C}=\mathrm{O}, \mathrm{C}-\mathrm{O}-\mathrm{C}$ dan deformasi $\mathrm{N}-\mathrm{H}$ menunjukkan spektrum kitin.

\section{Analisis Gugus Fungsi Kitosan Menggunakan FT-IR}

Gugus-gugus fungsi yang biasanya terkandung di dalam kitin dan kitosan tertera pada Tabel $1[6,7]$.

Tabel 1. Gugus fungsi yang terkandung dalam kitin dan kitosan

\begin{tabular}{lc}
\hline Gugus fungsi & $\begin{array}{c}\text { Bilangan Angka gelombang } \\
\left(\mathrm{cm}^{-1}\right)\end{array}$ \\
\hline $\mathrm{OH}$ & 3450,0 \\
$\mathrm{~N}-\mathrm{H}$ ulur & 3335,0 \\
$\mathrm{C}-\mathrm{H}$ ulur & 2878 \\
$\mathrm{NH}_{2}$ guntingan, N-H & 1661 \\
bengkokan & 1418 \\
$\mathrm{CH}_{3}$ & 1072,3 \\
$\mathrm{C}-\mathrm{O}-\mathrm{C}$ & $850-750$ \\
$\mathrm{NH}_{2}$ kibasan dan & 715,0 \\
pelintiran & \\
$\mathrm{N}-\mathrm{H}$ kibasan &
\end{tabular}

Gambar 3 (a) menunjukkan bahwa pada spektra kitosan pada rasio 01:15 dengan waktu reaksi 0,5 jam menunjukkan serapan vibrasi $\mathrm{OH}$, yaitu pada $3450,58 \mathrm{~cm}^{-1}$, dan vibrasi ulur N-H pada $3280,92 \mathrm{~cm}^{-1}$. Serapan pada $2879,72 \mathrm{~cm}^{-1}$ merupakan vibrasi ulur dari gugus $\mathrm{C}-\mathrm{H}$ metilen. Vibrasi guntingan $\mathrm{NH}_{2}$ dan $\mathrm{N}-\mathrm{H}$ bengkokan muncul pada bilangan gelombang $1654,92 \mathrm{~cm}^{-1}$. Serapan $\mathrm{CH}_{3}$ pada $1423,47 \mathrm{~cm}^{-1}$. Serapan $1072,42 \mathrm{~cm}^{-1}$ pada kitosan cangkang udang menunjukkan vibrasi C-O-C. Vibrasi kibasan N-H muncul pada $896,90 \mathrm{~cm}^{-1}$.

Spektrum-spektrum vibrasi kitosan yang diperoleh pada rasio 1:20 dengan waktu reaksi 0,5 jam ditunjukkan pada Gambar 3 (b). Serapan vibrasi OH, pada $3454,51 \mathrm{~cm}^{-1}$, dan vibrasi ulur N-H pada $3284,77 \mathrm{~cm}^{-1}$ sedangkan vibrasi pada $2879,72 \mathrm{~cm}^{-1}$ merupakan vibrasi ulur dari gugus $\mathrm{C}-\mathrm{H}$ metilen. $1064,71 \mathrm{~cm}^{-1}$ pada kitosan cangkang udang menunjukkan vibrasi C-O-C. Vibrasi kibasan N-H muncul pada $896,90 \mathrm{~cm}^{-1}$. Vibrasi guntingan $\mathrm{NH}_{2}$ dan $\mathrm{N}-\mathrm{H}$ bengkokan muncul pada bilangan gelombang $1656,85 \mathrm{~cm}^{-1}$. Serapan $\mathrm{CH}_{3}$ pada $1425,50 \mathrm{~cm}^{-1}$.
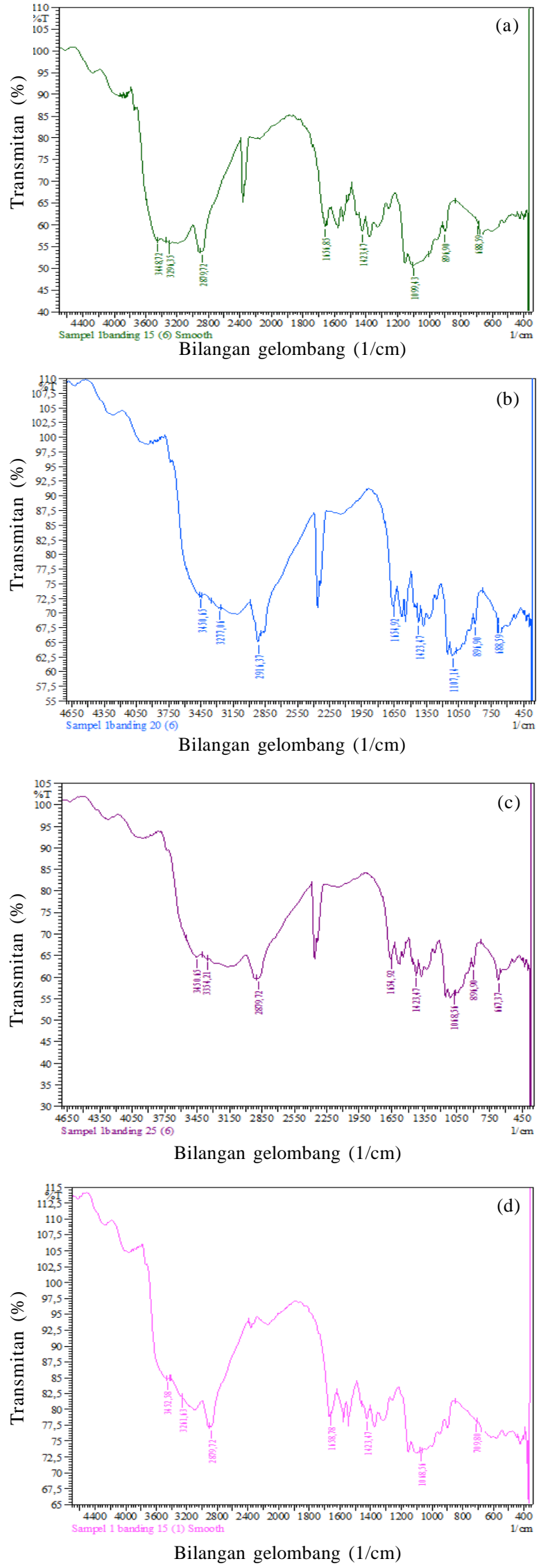

Gambar 3. Analisis gugus fungsi kitosan rasio (a) $1: 15$, 0,5 jam (b) 1:20, 0,5 jam (c) 1:25, 0,5 jam dan (d) 1:15, 3 jam 
Gambar 3 (c) memperlihatkan spektra kitosan pada rasio 01:25 dengan waktu reaksi 0,5 jam. Serapan pada bilangan gelombang $3452,58 \mathrm{~cm}^{-1}$ sebagai vibrasi $\mathrm{OH}$; $2879,72 \mathrm{~cm}^{-1}$ sebagai vibrasi ulur dari gugus $\mathrm{C}-\mathrm{H}$ metilen dan vibrasi ulur N-H pada $3284,77 \mathrm{~cm}^{-1}$. Serapan pada angka gelombang $1656,85 \mathrm{~cm}^{-1}$ sebagai vibrasi guntingan $\mathrm{NH}_{2}$ dan $\mathrm{NH}$, bilangan gelombang $1111,00 \mathrm{~cm}^{-1}$ menunjukkan vibrasi C-O-C. Kemudian adanya serapan $\mathrm{CH}_{3}$ pada $1423,47 \mathrm{~cm}^{-1}$. Vibrasi kibasan $\mathrm{N}-\mathrm{H}$ muncul pada $896,90 \mathrm{~cm}^{-1}$.

Spektrum yang serupa dengan hasil dengan Gambar 3(a) hingga Gambar 3(c), juga dihasilkan dari kitosan yang dibuat dengan rasio 1:15 pada waktu reaksi 3 jam (Gambar 3(d)) menunjukkan serapan vibrasi OH, yaitu pada $3444,87 \mathrm{~cm}^{-1}$, vibrasi ulur $\mathrm{N}-\mathrm{H}$ pada $3331,07 \mathrm{~cm}^{-1}$. Serapan lainnya adalah pada $2879,72 \mathrm{~cm}^{-1}$; $1653,00 \mathrm{~cm}^{-1} ; 1421,54 \mathrm{~cm}^{-1} ; 1107,14 \mathrm{~cm}^{-1} ; 1107,14 \mathrm{~cm}^{-1}$ dan $856,39 \mathrm{~cm}^{-1}$.

Perbedaan yang terjadi setelah tahap deasetilasi adalah tidak munculnya vibrasi gugus $\mathrm{C}=\mathrm{O}$ ulur dari gugus amida (-NHCO) pada $1680 \mathrm{~cm}^{-1}$, serta munculnya serapan pada $686,66 \mathrm{~cm}^{-1}$ yang merupakan vibrasi dari gugus kibasan dan pelintiran $\mathrm{NH}_{2}$. Serapan lainnya adalah pada $2879,72 \mathrm{~cm}^{-1}$ merupakan vibrasi ulur dari gugus $\mathrm{C}-\mathrm{H}$ metilen. Vibrasi guntingan $\mathrm{NH}_{2}$ dan $\mathrm{N}-\mathrm{H}$ bengkokan muncul pada bilangan gelombang $1653,00 \mathrm{~cm}^{-1}$ dan serapan $\mathrm{CH}_{3}$ pada $1421,54 \mathrm{~cm}^{-1}$. Adanya serapan pada $1107,14 \mathrm{~cm}^{-1}$ pada kitosan cangkang udang menunjukkan vibrasi C-O-C. Vibrasi kibasan $\mathrm{N}-\mathrm{H}$ muncul pada $856,39 \mathrm{~cm}^{-1}$.

\section{Pengaruh Waktu Reaksi dan Rasio Massa Kitin dengan Volume $\mathrm{NaOH}$ terhadap Rendemen}

Rendemen kitosan adalah kitosan yang dihasilkan dari proses deasetilasi terhadap kitin yang dihasilkan. Gambar 4 memperlihatkan rendemen kitosan yang dihasilkan pada waktu reaksi 0,5 jam hingga 3 jam dan variasi massa kitin dan volume $\mathrm{NaOH}$ 1:15 hingga 1:25. Makin bertambah volume $\mathrm{NaOH}$ dan waktu reaksi, rendemen yang diperoleh makin kecil. Menurunnya rendemen ini disebabkan oleh lepasnya gugus asetil

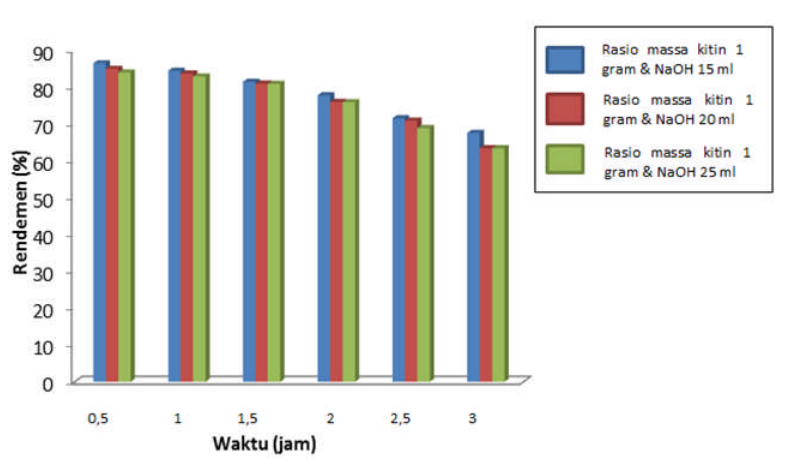

Gambar 4. Rendemen kitosan pada variasi waktu dan rasio maasa kitin dan volume $\mathrm{NaOH}$. yang terdapat di dalam kitin. Jumlah pelarut yang lebih banyak menyebabkan luas kontak antara pelarut dengan padatan pada saat proses, sehingga gugus asetil $\left(-\mathrm{COCH}_{3}\right)$ terlepas dari kitin. Selain itu lama reaksi menyebabkan molekul $\mathrm{NaOH}$ yang teradisi ke molekul kitin makin banyak sehingga menurunkan rendemen produk kitosan. Rendahnya rendemen kitosan meningkatkan kemurnian kitosan karena gugus asetil yang terlepas dari kitin makin banyak.

Rendemen kitosan 86,6\% terbesar terdapat pada rasio $1: 15(\mathrm{~b} / \mathrm{v})$ dengan waktu reaksi $0,5 \mathrm{jam}$. Rendemen terkecil 63,5\% terdapat rasio 1:25 (b/v) dengan waktu reaksi 3 jam.

\section{Kadar Air Kitosan}

Kadar air merupakan salah satu parameter penting mutu kitosan. Kadar air yang rendah dapat menekan atau mengurangi kerusakan pada kitosan, misalnya terhindar dari adanya aktivitas mikroorganisme. Nilai rata-rata kadar air kitosan yang diperoleh pada penelitian ini berkisar antara 1,21-1 \% (Gambar 5). Nilai kadar ini sudah memenuhi standar mutu kitosan yaitu $\geq 10 \%$.

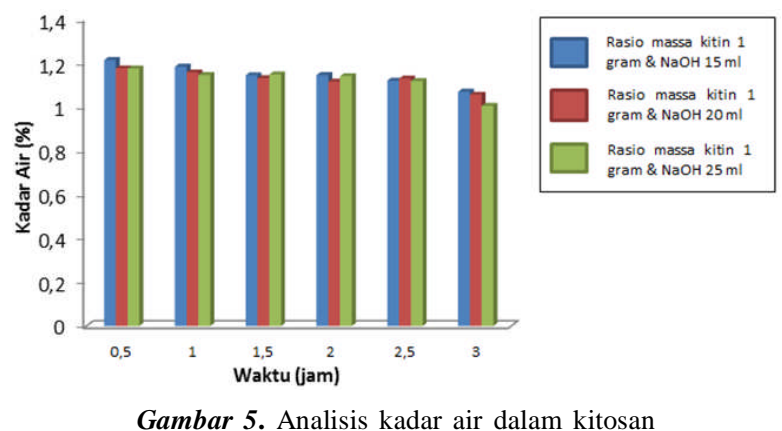

Dari analisis kadar air kitosan ditunjukkan bahwa variasi waktu reaksi dan rasio massa kitin dengan volume $\mathrm{NaOH}$ pada proses deasetilasi tidak memiliki pengaruh yang signifikan. Umumnya, kitosan yang baik memiliki kadar air kurang dari $6 \%$ [12]. Penelitian yang dilakukan oleh Ahing dan Wid (2016) menunjukkan kadar air yang diperoleh lebih tinggi yaitu 7,2\%. Hal ini disebabkan oleh perbedaan metode pengeringan yang digunakan.

\section{Kadar Abu Kitosan}

Hasil analisis kadar abu limbah ebi dan kitin dapat dilihat pada Tabel 2. Tingginya kadar abu pada limbah ebi $(28,5 \%)$ disebabkan oleh masih banyaknya kandungan mineral-mineral dalam dalam limbah tersebut. Setelah mengalami proses demineralisasi, kandungan mineral berkurang sehingga dengan kadar abu kitin lebih kecil yaitu $\geq 2,1 \%$.

Nilai rata-rata kadar abu kitosan yang diperoleh pada penelitian ini antara 1,9-1,1\% (Gambar 6). Hal ini disebabkan oleh berkurangnya mineral yang bereaksi dengan $\mathrm{NaOH}$ pada proses demineralisasi. 
Tabel 2. Hasil analisis kadar abu kitin dan cangkang udang

\begin{tabular}{cc}
\hline Bahan & Kadar abu(\%) \\
\hline Limbah ebi & 28,4 \\
Kitin & 2,1 \\
\hline
\end{tabular}

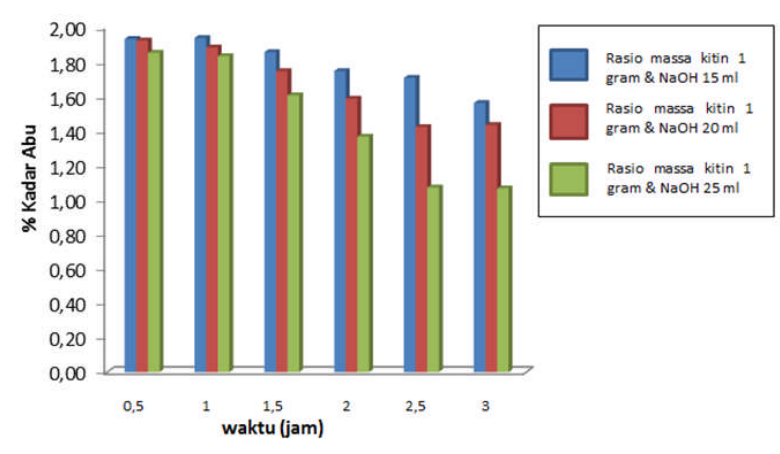

Gambar 6. Analisis abu dalam kitosan

Nilai kadar kitosan ini sudah memenuhi standar mutu yaitu $\geq 2 \%$.

Kadar abu kitosan tertinggi yaitu $1,9 \%$ diperoleh pada rasio 1:15 (b/v) dengan waktu reaksi 0,5 jam. Kadar abu terkecil yaitu $1,1 \%$ diperoleh pada rasio 1:25 (b/v) dengan waktu reaksi 3 jam. Mmkin besar rasio volume larutan $\mathrm{NaOH}$ dan lamanya waktu reaksi, makin kecil kadar abu kitosan yang dihasilkan. Makin besarnya volume $\mathrm{NaOH}$ yang digunakan pada proses deasetilasi, makin banyak gugus asetil pada kitin yang tereduksi dan mampu mengurangi sisa-sisa mineral yang terikat pada polimer, walaupun sudah dilakukan penghilangan mineral pada proses demineralisasi

\section{Derajat Deasetilasi Kitosan}

Derajat deasetilasi menunjukkan persentase gugus asetil yang hilang dari kitin sehingga dihasilkan kitosan [7]. Derajat deasetilasi merupakan salah satu parameter mutu kitosan. Gugus asetil pada kitosan dapat menurunkan efektivitas kitosan. Kitosan merupakan kitin dengan derajat deasetilasi lebih dari $70 \%$. [14]

Deasetilasi adalah proses pengubahan gugus asetil (- $\left.\mathrm{NHCOCH}_{3}\right)$ dari rantai molekular kitin menjadi gugus amina lengkap $\left(-\mathrm{NH}_{2}\right)$ yang dilakukan dengan penambahan $\mathrm{NaOH}$ konsentrasi tinggi. Reaksi deasetilasi kitin pada dasarnya adalah suatu reaksi hidrolisis amida dari $\alpha$-(1-4)-2-asetamida-2-deoksi-Dglukosa. Kemampuan fungsional kitosan utamanya

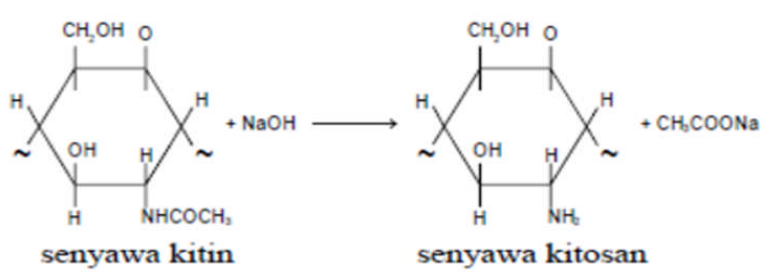

Gambar 7. Reaksi deasetilasi pada proses pembuatan kitosan [14]. bergantung pada derajat kimia reaktif yang tinggi gugus aminonya. Reaksi deasetilasi proses pembentukkan kitosan dapat dilihat pada Gambar 7. Reaksi yang terjadi merupakan reaksi adisi, yaitu reaksi masuknya gugus $\left(\mathrm{OH}^{-}\right)$kedalam gugus didalam kitin sehingga menyebabkan lepasnya gugus asetil dengan menghasilkan produk natrium asetat dan kitosan sebagai produk utama [14].

Hasil analisis derajat deasetilasi kitosan dapat dilihat pada Gambar 8. Derajat deasetilasi tertinggi dihasilkan pada perlakuan waktu reaksi deasetilasi 3 jam yaitu $86,1 \%$ pada rasio 1:25 (b/v). Sedangkan derajat deasetilasi terendah terdapat pada perlakuan waktu reaksi 0,5 jam yaitu $67,2 \%$ pada rasio $1: 15$.

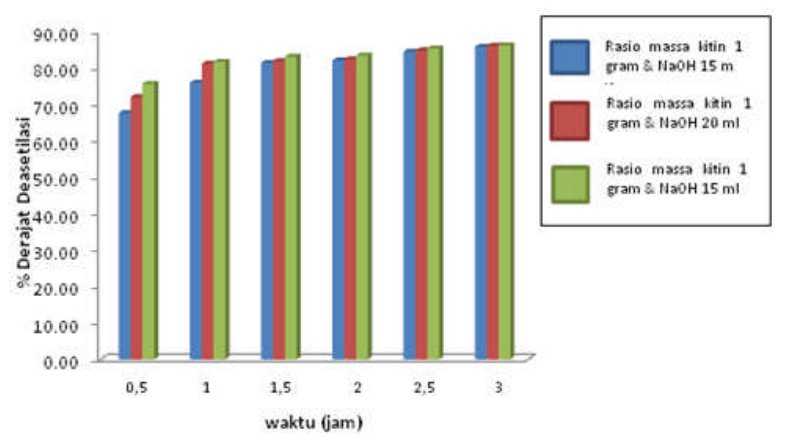

Gambar 8. Hasil analisis derajat deasetilasi kitosan

Patria (2013) mereaksikan $\mathrm{NaOH} 50 \%$ dengan kulit udang pada suhu $90{ }^{\circ} \mathrm{C}$ dan mendapatkan derajat deasetilasi $84,9 \%$. Selain itu diperoleh bahwa makin lama waktu dan makin tinggi suhu pemanasan derajat asetilasinya makin tinggi pula [15]

Kenaikan waktu reaksi mempengaruhi banyaknya molekul $\mathrm{NaOH}$ yang teradisi kitin dan menyebabkan gugus asetil yang terlepas pun makin banyak. Faktor pendorong terjadinya peningkatan derajat deasetilasi kitosan disebabkan oleh pengurangan gugus asetamida sehingga meningkatkan proses hidrolisis. Semakin kuat basa yang digunakan maka semakin tinggi gugus asetamida yang terbuang.

Derajat deasetilasi tertinggi dihasilkan pada perlakuan waktu reaksi deasetilasi 3 jam yaitu 86,1\% pada rasio 1:25 (b/v). Sedangkan derajat deasetilasi terendah terdapat pada perlakuan waktu reaksi 0,5 jam yaitu $67,2 \%$ pada rasio 1:15. Ketika volume larutan $\mathrm{NaOH}$ dinaikkan maka semakin besar derajat deasetilasi kitosan yang dihasilkan.

\section{KESIMPULAN}

Karakteristik kitosan yang disintesis menggunakan proses deasetilasi dipengaruhi oleh rasio massa kitin/ $\mathrm{NaOH}$ dan waktu reaksi. Derajat deasetilasi kitosan tertinggi 86,1\% diperoleh pada rasio massa kitin/ $\mathrm{NaOH} \mathrm{1:25} \mathrm{(b/v)} \mathrm{dan} \mathrm{waktu} \mathrm{reaksi} 3$ jam. Terjadi penurunan rendemen kitosan dari $86,6 \%$ menjadi $63,5 \%$ ketika rasio massa kitin/ $\mathrm{NaOH}$ dan waktu reaksi diubah 
dari 1:15 (0,5 jam) menjadi 1:25 (3 jam). Kitosan dengan rasio massa kitin/ $\mathrm{NaOH} \mathrm{1:25} \mathrm{memiliki} \mathrm{kadar} \mathrm{abu} \mathrm{1,6 \% ,}$ sedangkan pada rasio 1:15 kadar abu naik menjadi 1,9\%. Kadar air kitosan tidak dipengaruhi secara signifikan oleh rasio massa kitin/ $\mathrm{NaOH}$ dan waktu reaksi.

\section{UCAPAN TERIMAKASIH}

Penulis mengucapkan terima kasih kepada Kemenristekdikti atas pembiayaan penelitian ini melalui Skim Strategis Nasional tahun 2017.

\section{DAFTAR ACUAN}

[1]. K. Suneeta, P. Rath and A.S.H Kumar. "Chitosan from Shrimp Shell (Crangon crangon) and Fish scales (Labeorohita): Extraction and Characterization." African Journal of Biotechnology, vol 15, pp. 1258-1268, 2016.

[2]. S.L. Ihsani dan C.R. Widyastuti. "Sintesis Biokoagulan Berbasis Kitosan dari Kulit Udang Untuk Pengolahan Air Sungai Yang Tercemar Limbah Industri Jamu dengan Kandungan Padatan Tersuspensi Tinggi." Jurnal Bahan Alam Terbarukan, vol 4, pp 66-70, 2015.

[3]. A. Purwanti. "Evaluasi Proses Pengolahan Limbah Kulit Udang Untuk Meningkatkan Mutu Kitosan yang Dihasilkan.” Jurnal Teknologi, vol. 7, pp. 83-90, Juni 2014.

[4]. M.S Hossain and A. Iqbal. "Production and Characterization of Chitosan from Shrimp Waste." Journal of the Bangladesh Agricultural Universuty, vol. 12, pp. 153-160, 2014.

[5]. M. S. Benhabiles, R. Salah, H. Lounici, N. Drouiche, M. F. A. Goosen and N. Mameri. "Antibacterial Activity of Chitin, Chitosan, and Its Oligomers Prepared from Shrimp Shell Waste." Food Hydrocolloids, vol. 29, pp. 48-56, 2012

[6]. J. H. W. S. Long. "Synthesis and Characterisation of Chitosan from Shrimp Shells." B.E. Thesis. Universiti Tunku Abdul Rahman, Malaysia, 2013.
[7]. Y.S. Puvvada, S. Vankayalapati and S. Sukhavasi. "Extraction of chitin from chitosan from exoskeleton of shrimp for application in the pharmaceutical industry." International Current Pharmaceutical Journal, vol. 1(9), pp. 258-263, 2012.

[8]. S. Paul, A. Jayan, C.H. Sasikumar and S.M Cherian. "Extraction and Purification of Chitosan from Chitin Isolated from Sea Prawn (Fenneropenaeus indicus)." Asian Journal of Pharmaceutical and Clinical Research, vol. 7, pp. 201-204, 2012.

[9]. P. Nasution, S. Sumiati dan I.W. Wardana. "Studi Penurunan TSS, Turbidity dan COD dengan Menggunakan Kitosan dari Limbah Cangkang Keong Sawah (Pila ampullaceal) Sebagai Biokoagulan Dalam Pengolahan Limbah Cair PT. Sido Muncul, Tbk Semarang.” Jurnal Teknik Lingkungan, vol. 4, pp. 1-9, 2015.

[10]. Drastinawati. "Pemanfaatan Khitin dan Khitosan dari Kulit Udang Sebagai Material Penyerap Ion Kafdmium, Tembaga dan Timbal.” Magister Tesis, Universitas Andalas, Indonesia, 2002.

[11]. P. Sugita, T. Wukirsari, A. Sjahriza dan D. Wahyono. Kitosan Sumber Biomaterial Masa Depan. Bogor: IPB Press, 2009.

[12]. F. A. Ahing and N. Wid. "Extraction and Characterization of Chitosan from Shrimp Shell Waste in Sabah." Transactions on Science and Technology, vol. 3, pp. 227-237, 2016.

[13]. I. Younes and M. Rianudo. "Chitin and Chitosan Preparation from Marine Sources." Structure, Properties and Applications". Marine Drugs, vol. 13,pp. 1133-1174, 2015.

[14]. M. Riswan. "Pembuatan Kitosan Dari Limbah Cangkang Bekicot dengan Variasi $\mathrm{NaOH}$ Pada Tahap Deasetilasi.” Laporan Akhir Diploma III, Politeknik Sriwijaya, Indonesia, 2014.

[15] A. Patria. "Production and Characterization of Chitosan from Shrimp Shells Waste." Aquaculture, Aquarium, Conservation \& LegislationInternational Journal of the Bioflux Society, vol. 6, pp. 339-344, 2013. 